\title{
Bioactive fragments of laminin and collagen chains: lesson from the testis
}

\author{
Huitao $\mathrm{Li}^{1,2, *}$, Shiwen $\mathrm{Liu}^{1,2, *}$, Siwen $\mathrm{Wu}^{1,2}$, Linxi $\mathrm{Li}^{1,2}$, Renshan $\mathrm{Ge}^{1}$ and C Yan Cheng ${ }^{1,2}$ \\ ${ }^{1}$ The Second Affiliated Hospital \& Yuying Children's Hospital, Wenzhou Medical University, Wenzhou, Zhejiang, \\ China and ${ }^{2}$ The Mary M. Wohlford Laboratory for Male Contraceptive Research, Center for Biomedical Research, \\ Population Council, New York, New York, USA
}

Correspondence should be addressed to C Y Cheng; Email: y-cheng@popcbr.rockefeller.edu or ccheng@rockefeller.edu

*(H Li and S Liu contributed equally to this work)

\begin{abstract}
Recent studies have shown that the testis is producing several biologically active peptides, namely the F5- and the NC1-peptides from laminin- $\gamma 3$ and collagen $\alpha 3$ (IV) chain, respectively, that promotes blood-testis barrier (BTB) remodeling and also elongated spermatid release at spermiation. Also the LG3/4/5 peptide from laminin- $\alpha 2$ chain promotes BTB integrity which is likely being used for the assembly of a 'new' BTB behind preleptotene spermatocytes under transport at the immunological barrier. These findings thus provide a new opportunity for investigators to better understand the biology of spermatogenesis. Herein, we briefly summarize the recent findings and provide a critical update. We also present a hypothetical model which could serve as the framework for studies in the years to come.

Reproduction (2020) 159 R111-R123
\end{abstract}

\section{Introduction}

Throughout the epithelial cycle of spermatogenesis which has a duration of about 12.8 (stages I-XIV), 8.6 (stages I-XII) and 16 (stages I-XII) days in the testis of rats, mice and humans respectively (Heller and Clermont 1963, Clermont 1972, de Kretser and Kerr 1988, Hess and de Franca 2008, Muciaccia et al. 2013), dynamic remodeling of cell junction takes place continuously at the Sertoli cell-cell and Sertoligerm cell interface to support the various events of spermatogonial stem cell self renewal through mitotic proliferation, meiosis, spermiogenesis and the release of sperm at spermiation (Hermo et al. 2010a,c, O'Donnell et al. 2011, Cheng and Mruk 2015). This is necessary to facilitate timely communications between testicular cells in the seminiferous epithelium to support spermatogenesis. It is noted that the detailed morphological events pertinent to cell junction remodeling have been delineated, and some of the involving ultrastructures and biomolecules that modulate these events have been identified in recent years (Cheng and Mruk 2002, 2010, Hermo et al. 2010b,c, Vogl et al. 2013, 2014, Berruti and Paiardi 2014). Nonetheless, the precise molecular mechanism that regulates these cellular events locally across the seminiferous epithelium in the testis to support the epithelial cycle remains relatively unexplored. Herein, we seek to summarize some recent findings in this area of research, highlighting the latest advances and to identify specific areas that deserve future investigation. We also seek to understand the advances made in this area of research in light of findings based on studies in other epithelia. This should provide a better framework for functional studies in future investigations.

\section{ES (ectoplasmic specialization) - apical ES and basal ES}

The ES is a testis-specific, actin-rich adherens junction, found at the Sertoli cell-cell interface near the basement membrane designated basal ES, which coexists with the actin-based tight junction (TJ) and gap junction (G) (Vogl et al. 2008, Wong et al. 2008, Berruti and Paiardi 2014). These actin-based junctions, together with the intermediate filament-based desmosome, in turn, constitute the blood-testis barrier (BTB), which is considered to be one of the tightest blood-tissue barriers in the mammalian body (Setchell 2008, Mital et al. 2011, Pelletier 2011, Cheng and Mruk 2012, Franca et al. 2012, Stanton 2016). The ES is also found at the Sertoli cell-spermatid interface (steps 8-19 or 8-16 in the rat and mouse testis, respectively) called apical ES (Vogl et al. 2008, Wong et al. 2008, Berruti and Paiardi 2014). But unlike the basal ES that coexists with TJ and GJ, once the apical ES appears 
between Sertoli cells and step 8 spermatids in stage VIII tubules in the rodent testis, apical ES replaces the desmosome and G) found at the Sertoli-spermatid (steps 1-7) interface, serving as the only anchoring device to adhere developing haploid spermatids onto the Sertoli cell in the seminiferous epithelium until the release of sperm at spermiation ( $\mathrm{O}^{\prime}$ Donnell et al. 2011, O'Donnell 2014). Ultrastructurally, the apical and the basal ES look similar wherein an array of actin filaments that aligned as bundles are sandwiched in-between the Sertoli cell endoplasmic reticulum (ER) and the apposing Sertoli-spermatid plasma membranes (i.e. apical ES) vs Sertoli cell-cell plasma membranes (i.e. basal ES) (Fig. 1). Except that in the apical ES, there is only a single array of actin filament bundles vs two arrays of actin filament bundles in the basal ES (Fig. 1). When examined by electron microscopy at the ultrastructural levels, spermatids do not appear to contribute structurally to the apical ES. However, in late stage VII through early VIII of the epithelial cycle, the ES undergoes some structural modifications wherein giant endocytic vesicles are formed at the ES and designated tubulobulbar (TBC) complex, which carries the 'old' ES proteins to be recycled to assemble 'new' ES at the apical and basal sites (Vogl et al. 2013) (Fig. 1). This thus avoids de novo protein synthesis throughout the epithelial cycle of spermatogenesis due to the limited resources and space in the seminiferous epithelium to support the production of millions of sperm per day from the testis after puberty. However, at the molecular level, the apical ES is considerably different from the basal ES. For instance, elongating/elongated spermatids specifically express nectin 3 (Ozaki-Kuroda et al. 2002, Inagaki et al. 2006), JAM-C (Gliki et al. 2004), VE cadherin (Aivatiadou et al. 2007), and laminin- $\alpha 3 ß 3 \gamma 3$ trimeric ligand (Koch et al. 1999, Yan and Cheng 2006) as adhesion molecules, not found in Sertoli cells, and are crucial to support stability and integrity of spermatidSertoli cell adhesion. On the other hand, Sertoli cells express nectin 1, nectin 2, JAM-A, JAM-B, E-cadherin, $\mathrm{N}$-cadherin, and $\alpha 6 \beta 1$-integrin to form the functional adhesion protein complexes with the corresponding adhesion proteins expressed by spermatids at the apical ES (Palombi et al. 1992, Salanova et al. 1995, Mruk and Cheng 2004, Setchell 2008, Berruti and Paiardi 2014). More important, studies have shown that Rap1 (Ras-related protein 1), a small GTPase, serves as a crucial central organizer of cell architecture and junction stability at the apical ES through its effects on F-actin cytosekeleton, and with the participation of the upstream and downstream mediators of Rap1, which include Rho GTPase, Cdc42 GTPase, and cell polarity protein Par (partitioning-defective protein), as well as integral membrane proteins VE cadherin, nectin 3 and JAM-C based on studies in vivo using genetic models (Aivatiadou et al. 2007, 2009, Berruti and Paiardi 2014, Berruti et al. 2018).
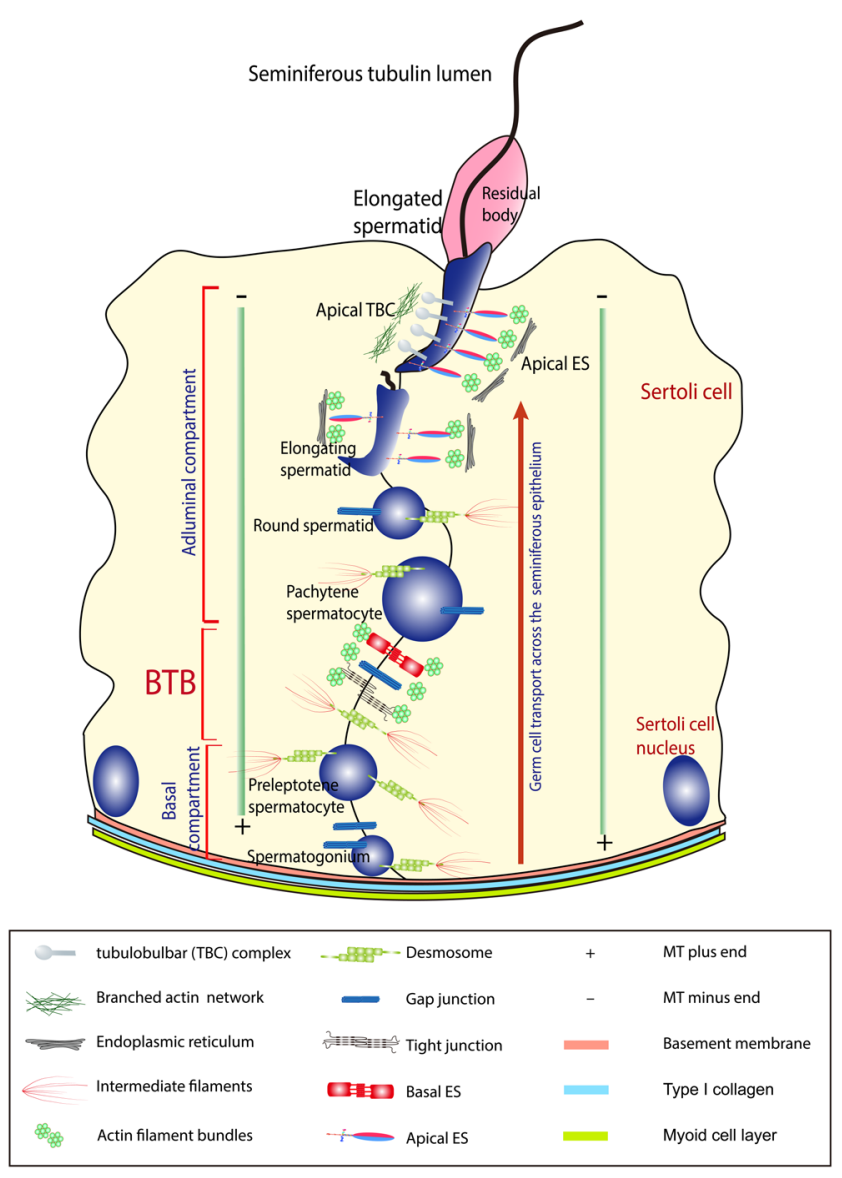

Figure $1 \mathrm{~A}$ schematic drawing that illustrates the morphological features of the apical ES and basal ES in the seminiferous epithelium of adult rat testes. This schematic drawing illustrates some of the notable features of the cross-section of a stage VII tubule, composed to adjacent Sertoli cells and germ cells at different stages of their development, as discussed in this review. Ectoplasmic specialization (ES) is typified by the presence of an array of actin filament bundles sandwiched between cisternae of endoplasmic reticulum (ER) and the apposing plasma membranes of Sertoli cells and step 8-19 spermatids at the Sertoli-spermatid interface (apical ES), but with two arrays of actin filament bundles at the basal ES. The basal ES, together with the tight junction (TJ) and gap junction, along with the intermediate filament-based desmosome constitute the blood-testis barrier (BTB), which in turn divides the seminiferous epithelium into the basal and adluminal (apical) compartments. Also noted is the progressive transport of germ cells across the seminiferous epithelium from the base to the lumen of the tubule. In stage VII tubule, the concave (ventral) side of spermatid head, apical ES undergoes extensive remodeling, creating an ultrastructure known as the apical TBC (tubulobulbar complex). The apical ES represents numerous endocytic vesicles used to support endocytosis and recycling of apical ES protein (such as adhesion protein complexes of integrinlaminin, necin-afadin, or cadherin-catenin complex), which is facilitated by the extensive branching of the actin filament bundles at the site to destabilize apical ES to facilitate endocytic protein trafficking events. A similar ultrastructure known as basal TBC can also be found at the BTB to support BTB remodeling. The seminiferous epithelium is laid on the basement membrane, constituted mostly by type IV collagen, laminins (mostly laminin- $\alpha 2$ chains), heparan sulfate proteoglycans and entactin, to be followed by the collagen type I layer, and then the peritubular myoid cell layer. 


\section{Role of F5-peptide in junction dynamics in the testis}

In mammalian tissues, laminin chains are usually restrictively expressed at the basal lamina, which is the homogeneous extracellular matrix (ECM) substance deposited at the base of virtually all cell epithelia. In the testis, the basement membrane is a modified form of ECM, which is derived from Sertoli cells and contributed, at least in part, by peritubular myoid cells, appearing as a homogenous layer of $\sim 0.15 \mu \mathrm{m}$ thick (Dym 1994, Siu and Cheng 2004a, 2008) in the tunica propria (Fig. 1). In rodent testes, the basement membrane is constituted largely by type IV collagen and laminins (e.g., laminin- $\alpha 2$ chain), and also heparin sulfate proteoglycan (Hadley and Dym 1987) and entactin (Lian et al. 1992). Interestingly, laminin- $\gamma 3$ is one of the first laminin chains shown to be deposited outside the basement membrane in the mouse testis, at the apical ES (Koch et al. 1999). Subsequent studies have shown that laminin- $\gamma 3$ (Siu and Cheng 2004b) form a functional trimeric ligand with laminin- $\alpha 3$ and laminin-B3 at the apical ES (Yan and Cheng 2006). More important, this trimeric laminin- $\alpha 3 \beta 3 \gamma 3$ ligand contributed by spermatids (Yan and Cheng 2006) creates a bona fide cell adhesion protein complex with $\alpha 6 \beta 1$ integrin contributed by Sertoli cells (Palombi et al. 1992, Salanova et al. 1995, 1998) at the apical ES (Mulholland et al. 2001, Siu and Cheng 2004b, Yan and Cheng 2006) (Fig. 2). Studies using different genetic models have also demonstrated the physiological significance of laminin chains in the mammalian body (Table 1). Other studies have shown that biologically active fragments are generated from laminin chains via the action of MMPs (matrix metalloproteinases) in the basal lamina of other epithelia which are capable of regulating cell adhesion, cell migration, vascular permeability, cell apoptosis, cell proliferation and cell differentiation (Sato et al. 1994, Tang and Saito 2018a,b, Yan et al. 2007) (Table 2). Studies in the testis have shown that domain IV released from laminin- $\gamma 3$ chain, likely via the action of MMP-2 (Siu and Cheng 2004b), is capable of perturbing Sertoli cell TJ-permeability barrier function based on studies in vitro (Yan et al. 2008). Subsequent studies have mapped the biologically active domain to a stretch of peptide sequence of about 50 amino acid residues in the domain IV of laminin- $\gamma 3$ chain designated F5-peptide (Su et al. 2012) (Fig. 2). Overexpression of this F5-peptide (following cloning of its cDNA into the mammalian expression vector $\mathrm{pCl}$-neo) in Sertoli cells cultured in vitro or the testis in vivo is able to induce reversible Sertoli cell BTB disruption (Su et al. 2012, Gao et al. 2016). More important, F5-peptide is rapidly taken up by Sertoli cells in the testis in vivo via the drug transporter S1c15a1 (Su et al. 2015), illustrating that generation of the F5-peptide from laminin- $\gamma 3$ chain via the action of MMP-2 outside the Sertoli cells in the seminiferous epithelium can also be taken up by Sertoli

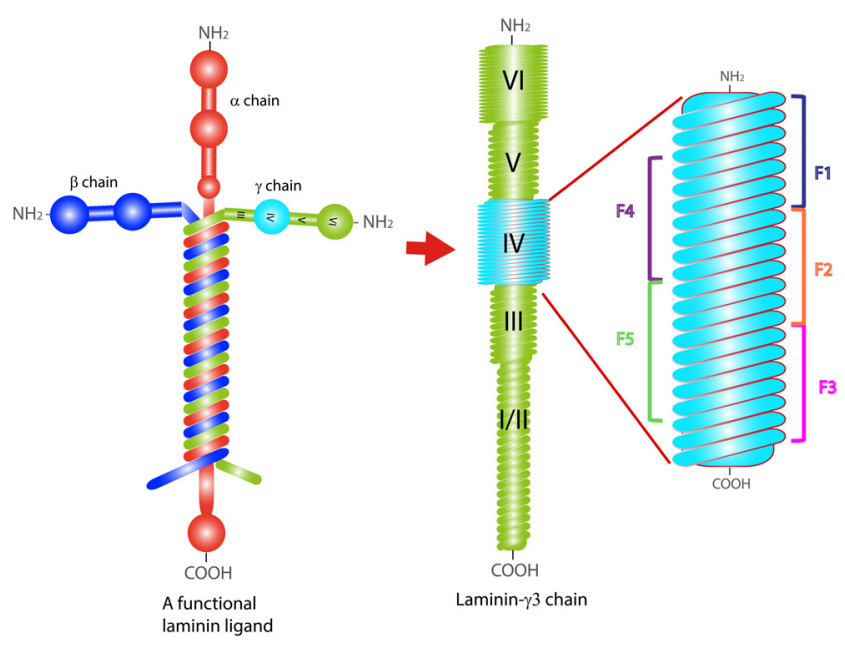

Figure 2 A schematic drawing that illustrates the structural features of a functional laminin ligand constituted by three laminin chains, one each of $\alpha, \beta$ and $\gamma$ chains, and the functional domains of the laminin- $\gamma 3$ chain. Studies have shown that the functional laminin-333 composed of laminin- $\alpha 3,-\beta 3$, and $-\gamma 3$ chains is a putative cell adhesion protein expressed by elongated spermatids that form a bona fide adhesion complex with $\alpha 6 ß 1$-integrin expressed by Sertoli cells. However, domain IV of laminin- $\gamma 3$ chain is now known to generate the F5-peptide endogenously possibly through the action of MMP-2, which is capable of inducing BTB remodeling but also potentiating the breakdown of apical ES at late stage VIII tubule to coordinate the cellular events of spermiation and BTB remodeling at stage VIII of the cycle (see text for details).

cells through the drug transport S1c15a1, which, in turn, modulates Sertoli cell permeability barrier function. Furthermore, studies have shown that the F5-peptide exerts its disruptive effects in Sertoli cells by modifying F-actin organization across the cell cytosol, but also capable of perturbing $\mathrm{F}$-actin organization across the seminiferous epithelium through disruptive changes in the spatiotemporal expression of p-FAK-Y407 (Su et al. 2012), which was earlier shown to be a crucial regulator of BTB integrity (Lie et al. 2012). Thus, it is not entirely unexpected that overexpression of F5-peptide in the testis also induces germ cell exfoliation, in particular elongating/elongated spermatids, in the testis (Su et al. 2012, Gao et al. 2016) since the apical ES utilizes F-actin for attachment of its adhesion protein complexes, and it is considered to be an atypical adherens junction (Mulholland et al. 2001, Vogl et al. 2008, Wong et al. 2008). In this context, it is of interest to note that p-FAK-Y407 (Lie et al. 2012, Gao et al. 2016) and its closely related activated form P-FAK-Y397 (Siu et al. 2003b, Wan et al. 2013) are known regulators of basal ES/BTB and also apical ES function, but they have differential function on cell adhesion in the testis. For instance, p-FAK-Y407 confers both basal ES/BTB function and apical ES integrity, whereas p-FAK-Y397 confers apical ES integrity but it induces basal ES/BTB disruption (Lie et al. 2012). This conclusion was reached based on an in vitro study using primary cultures of 
R114 H Li, S Liu and others

Table 1 Selected mouse models of deletion of laminin chains and the associated phenotypes.

\begin{tabular}{|c|c|c|c|c|c|}
\hline Laminin chain & Mouse model & Approach & Animal/cell types & Phenotypes & References \\
\hline$\alpha 2$ & $\begin{array}{l}\text { Laminin- } \alpha 2 \text { chain } \\
\text { deficient } d y^{3 k} / d y^{3 K} \\
\text { mice }\end{array}$ & $\begin{array}{l}\text { Laminin- } \alpha 2 \text { chain } \\
\text { deficiency }\end{array}$ & Mouse & $\begin{array}{l}\text { Male infertility due to } \\
\text { defects in basement } \\
\text { membrane because of } \\
\text { laminin- } \alpha 2 \text { deficiency } \\
\text { which also reduces } \\
\text { laminin- } \gamma 3 \text { chain }\end{array}$ & Häger et al. 2005 \\
\hline$\alpha 3$ & $\begin{array}{l}\text { Inactivation of the } \\
\text { Lama3 gene in basal } \\
\text { keratinocytes of adult } \\
\text { mice }\end{array}$ & $\begin{array}{l}\text { Targeted disruption } \\
\text { of the laminin- } \alpha 3 \\
\text { gene }\end{array}$ & Mouse & $\begin{array}{l}\text { Skin inflammation and } \\
\text { fibrosis }\end{array}$ & Pesch et al. 2017 \\
\hline$\alpha 4$ & $\begin{array}{l}\text { Laminin- } \alpha 4 \text { null } \\
\qquad\left(\text { Lama }^{-/-}\right) \text {mice }\end{array}$ & $\begin{array}{l}\text { Mice lacking the } \\
\text { presynaptic } \\
\text { organizer } \\
\text { laminin- } \alpha 4 \text { gene }\end{array}$ & Mouse & $\begin{array}{l}\text { Disruption of nerve } \\
\text { endings development }\end{array}$ & Samuel et al. 2012 \\
\hline$\beta 2$ & $\begin{array}{l}\text { Insertion of a neo } \\
\text { cassette in exon } 3 \\
\text { (the second coding } \\
\text { exon) of the } \\
\text { laminin- } \beta 2 \text { gene }\end{array}$ & $\begin{array}{l}\text { Disruption of } \\
\text { laminin- } \beta 2 \text { gene }\end{array}$ & Mouse & $\begin{array}{l}\text { Alterations in morphology } \\
\text { and function of the CNS }\end{array}$ & Libby et al. 1999 \\
\hline$\beta 2$ and $\gamma 3$ & $\begin{array}{l}\text { Whole body gene } \\
\text { knockout }\end{array}$ & $\begin{array}{l}\text { Ablation of } \\
\text { laminin- } \beta 2 \text { and } \\
\text { laminin- } \gamma 3 \text { genes }\end{array}$ & Mouse & $\begin{array}{l}\text { Defects in brain } \\
\text { development }\end{array}$ & Radner et al. 2013 \\
\hline$\gamma 1$ (laminin-511) & Laminin $-\gamma 1 \mathrm{KO}$ mice & $\begin{array}{l}\text { Specific deletion of } \\
\text { laminin- } \gamma 1 \text { gene in } \\
\text { keratinocytes }\end{array}$ & $\begin{array}{l}\text { Mouse primary } \\
\text { melanocytes }\end{array}$ & $\begin{array}{l}\text { Defects in melanocyte } \\
\text { migration and } \\
\text { differentiation }\end{array}$ & Ustun et al. 2019 \\
\hline$\gamma 1$ (laminin-211) & $\begin{array}{l}\text { Mice lacking } \\
\text { laminin- } \gamma 1 \text { expression } \\
\text { in keratinocytes }\end{array}$ & $\begin{array}{l}\text { Specific deletion of } \\
\text { laminin- } \gamma 1 \text { in } \\
\text { epidermis }\end{array}$ & Mouse & $\begin{array}{l}\text { Defects in hair morpho- } \\
\text { genesis }\end{array}$ & $\begin{array}{l}\text { Fleger-Weckmann et al. } \\
2016\end{array}$ \\
\hline
\end{tabular}

Sertoli cells for the overexpression of their full-length cDNAs (i.e., wild-type (WT)) vs different constitutively active (i.e., phosphomimetic mutants) and constitutively inactive (i.e., non-phosphorylable mutants) (Lie et al. 2012). For instance, overexpression of p-FAK-Y397E mutant (a phosphomimetic and constitutively active mutant of p-FAK-Y397) in adult rat testes in vivo promotes apical ES function by delaying spermiation since F-actin remained robustly expressed at the apical ES to support elongated spermatid adhesion (Wan et al. 2013). On the other hand, overexpression of p-FAK-Y407E mutant (a phosphomimetic and constitutively active mutant of p-FAK-Y407) in rat or primary human Sertoli cells promotes the Sertoli cell TJ-permeability barrier, capable of blocking the PFOS (perfluorooctanesulfonate, an environmental toxicant known to mediate TJ-barrier disruption (Wan et al. 2014))-induced TJ-barrier disruption (Wan et al. 2014, Chen et al. 2017a). Collectively, these findings illustrate that the testis is producing the regulatory F5-peptide locally at the apical ES site by potentiating the degeneration of apical ES to facilitate sperm release at spermiation (Gao et al. 2016). This cellular event is mediated through the signaling protein p-FAK-Y407 (Su et al. 2012, Gao et al. 2016), probably also p-FAK-Y397, downstream. Additionally, the F5-peptide also acts as an autocrine factor to affect other functions, such as by inducing BTB remodeling at the basal ES near the basement membrane. In this context, it is of interest to note that based on this physiological activity of the F5-peptide wherein it can effectively modify the transport function of the Sertoli cell BTB as noted in earlier studies (Su et al. 2012, Gao et al. 2016), the F5-peptide can serve as an adjuvant to modify the BTB permeability/transport function, thereby improving bioavailability of a drug considerably if co-administering into male rodents. In fact, a recent report has confirmed this possibility since it was shown that co-administration of F5-peptide through its overexpression with a drug (e.g. the non-hormonal male contraceptive adjudin, earlier shown to have poor bioavailability (Cheng et al. 2005)) considerably improved the efficacy of adjudin to induce reversible male contraception in adult rats (Chen et al. 2019). In brief, future investigations are warranted to examine if the F5-peptide can modify other bloodtissue barriers (e.g. the blood-brain barrier, BBB) so that it can facilitate the transport of therapeutic drugs across the BBB to treat illnesses, such as glioma, in the brain.

\section{Role of NC1-peptide in junction dynamics in the testis}

In the rodent testis, besides laminins, heparan sulfate proteoglycans and entactin, type IV collagen is the major structural component of the basement membrane (Dym 1994, Lin 2004, Siu and Cheng 2004a, 2008). Type IV collagen is a triple helical structure consisting of three collagen $\alpha$ chains of $\alpha 1, \alpha 2, \alpha 3, \alpha 4, \alpha 5$, or $\alpha 6$, either a homotrimeric or a heterotrimer structure (Fig. 3), wherein collagen $\alpha 3$ (IV) is the predominant chain. Each collagen $\alpha 3$ (IV) chain consists of a short 7S domain (with a short 
Table 2 Biologically active fragments of laminin chains in selected study models.

\begin{tabular}{|c|c|c|c|c|c|}
\hline $\begin{array}{l}\text { Laminin ligand or } \\
\text { chain }\end{array}$ & Protease partner & Cleavage/regulation & Animal/cell types & Biological effects & References \\
\hline$\alpha 2$ & $\begin{array}{l}\text { MMP-9, MMP-10, } \\
\text { MMP-12, MMPs }\end{array}$ & $\begin{array}{l}\text { Induction of MMP-9, } \\
\text { MMP-10, MMP-12, } \\
\text { MMPs linked to GBM } \\
\text { destruction }\end{array}$ & Glomerular podocytes & $\begin{array}{l}\text { Laminin- } \alpha 2 \text { chain } \\
\text { fragments activate } \\
\text { focal adhesion } \\
\text { kinase (FAK) on } \\
\text { glomerular } \\
\text { podocytes in vitro } \\
\text { and in vivo }\end{array}$ & $\begin{array}{l}\text { Toss et al. } \\
2019\end{array}$ \\
\hline$\alpha 5$ (LAMA5) & MMP1 & $\begin{array}{l}\text { Proteolytic cleavage of } \\
\text { laminin }\end{array}$ & $\begin{array}{l}\text { MDCK, 21D1, and } \\
\text { 21D1-MMP1 cells }\end{array}$ & $\begin{array}{l}\text { Promotes } \\
\text { angiogenesis of } \\
\text { endothelial cells }\end{array}$ & $\begin{array}{l}\text { Gopal et al. } \\
2016\end{array}$ \\
\hline$\beta 1$ (Laminin-111) & MMP2 & $\begin{array}{l}\text { MMP2 Cleaves the } \\
\beta 1 \text {-Chain of Laminin-111 }\end{array}$ & Embryonic stem cells & $\begin{array}{l}\text { Regulates cell } \\
\text { adhesion and } \\
\text { migration and } \\
\text { interacts with } \\
\text { mouse ESCs } \\
\text { (embryonic stem } \\
\text { cells) via } \\
\alpha 3 \beta 1 \text {-integrin } \\
\text { receptors }\end{array}$ & $\begin{array}{l}\text { Horejs et al. } \\
2014\end{array}$ \\
\hline$\gamma 2$ (laminin-332) & MMP-9 & $\begin{array}{l}\text { Proteolytic cleavage of } \\
\text { laminin }\end{array}$ & Stromal cells & $\begin{array}{l}\text { Modulates cell } \\
\text { attachment, } \\
\text { migration, } \\
\text { differentiation and } \\
\text { proliferation }\end{array}$ & $\begin{array}{l}\text { Silva et al. } \\
2018\end{array}$ \\
\hline laminin-111 & MMP-2, MMP-9 & $\begin{array}{l}\text { Proteolytic cleavage of } \\
\text { laminin }\end{array}$ & Malignant cells & $\begin{array}{l}\text { Facilitates } \\
\text { metastatic spread } \\
\text { by allowing tumor } \\
\text { cells to penetrate } \\
\text { tissues }\end{array}$ & $\begin{array}{l}\text { Kikkawa et al. } \\
2013\end{array}$ \\
\hline $\begin{array}{l}\text { laminin-111,-211, } \\
-411 \text {, and }-511\end{array}$ & $\begin{array}{l}\text { Neutrophil elastase (NE) } \\
\text { and matrix } \\
\text { metalloproteinase } 9 \\
\text { (MMP9) }\end{array}$ & $\begin{array}{l}\text { Proteolytic cleavage of } \\
\text { laminin }\end{array}$ & Dormant cancer cells & $\begin{array}{l}\text { Laminin } \\
\text { remodeling to } \\
\text { awaken cancer } \\
\text { cells }\end{array}$ & $\begin{array}{l}\text { Albrengues } \\
\text { et al. } 2018\end{array}$ \\
\hline $\begin{array}{r}\text { laminin-332 } \\
\text { (laminin-5) }\end{array}$ & $\begin{array}{l}\text { MMP-2, MMP-14, bone } \\
\text { morphogenetic } \\
\text { protein-1 (BMP-1), and } \\
\text { mammalian Tolloid } \\
\text { (mTLD) }\end{array}$ & $\begin{array}{l}\text { Proteolytic cleavage of } \\
\text { laminin } \gamma 2\end{array}$ & $\begin{array}{l}\text { TAM (tumor-associated } \\
\text { macrophages)-like cells }\end{array}$ & $\begin{array}{l}\text { Promotes monocyte } \\
\text { differentiation }\end{array}$ & $\begin{array}{l}\text { Kamoshida } \\
\text { et al. } 2014\end{array}$ \\
\hline Laminin & MMP11 & $\begin{array}{l}\text { Proteolytic cleavage of } \\
\text { laminin }\end{array}$ & Zebrafish & $\begin{array}{l}\text { Regulates } \\
\text { fibronectin levels }\end{array}$ & $\begin{array}{l}\text { Jenkins et al. } \\
2016\end{array}$ \\
\hline
\end{tabular}

signal peptide at its $\mathrm{N}$-terminal end) of $\sim 15$ amino acids at its $\mathrm{N}$-terminus, to be followed by a long collagenous domain of $\sim 1400$ residues of Gly-Xaa-Yaa repeats, and a C-terminal NC1 (non-collagenous 1) domain of $\sim 230$ residues (Timpl et al. 1981, Hudson et al. 1993) (Fig. 3). Collagens are scaffolding proteins known to provide structural support to epithelial and endothelial cells, such as Sertoli cells in the seminiferous epithelium. The significance of collagen chains to maintain cell and tissue integrity has been demonstrated in studies using genetic models (Table 3). Studies have shown TNF $\alpha$ released from Sertoli cells can trigger activation of MMP-9 to release the NC1 domain and other peptides through limited proteolysis (Siu et al. 2003a), which are physiologically active peptides (Ortega and Werb 2002). For instance, NC1 domain of various collagen chains, called tumstatin, endostatin, or constatin, was shown to serve as ligand to regulate morphogenesis, cell adhesion, cell migration, proliferation, angiogenesis, and apoptosis in different cell types via its interactions with cell-surface receptors, such as integrins (Ackley et al. 2001, Ortega and Werb 2002, Hamano and Kalluri 2005, Assadian and Teodoro 2008, Sudhakar and Boosani 2008, Rebustini et al. 2009, Barczyk et al. 2010). These findings thus prompted us to investigate if NC1-peptide released in the basement membrane of the testis would have similar effects to the testis function. Indeed, when NC1-peptide from collagen $\alpha 3$ (IV) in the testis was cloned into pCl-neo for its overexpression, or through the use of expression vectors (such as pET30 Ek/LIC expression vector or pTracerCMV2 expression vector) to obtain its recombinant protein from $E$. coli or human embryonic kidney cell line Lenti-X 293 cells, respectively, for studies in vitro or in vivo. Overexpression of NC1-peptide or the use of NC1 recombinant peptide was shown to perturb Sertoli cell TJ-permeability barrier function in vitro and in vivo (Wong and Cheng 2013, Chen et al. 2017b). More importantly, NC1-peptide exerts its effects to induce BTB remodeling and apical ES degeneration to promote germ 


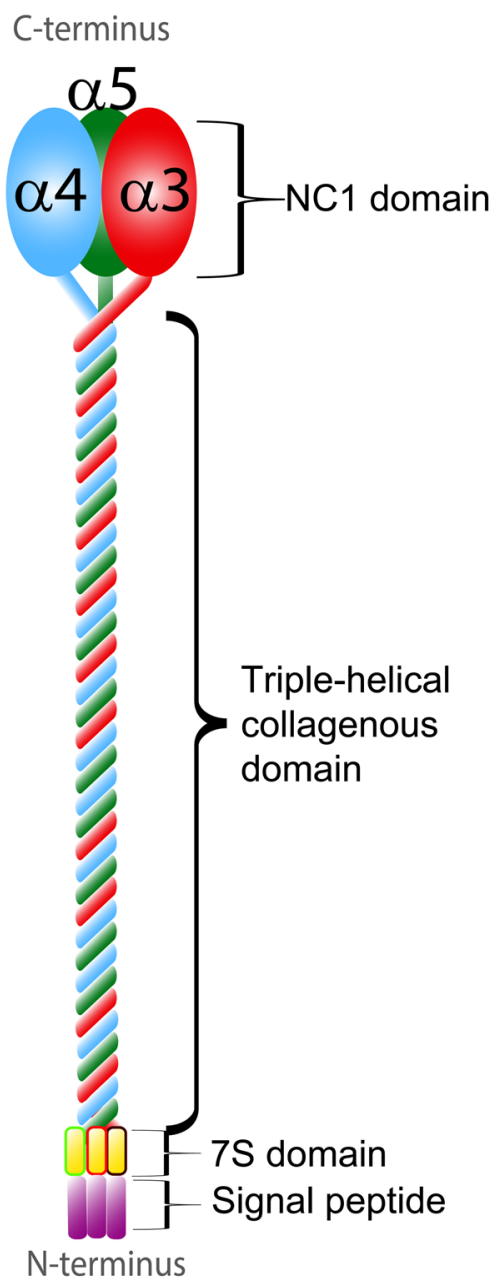

\section{A functional collagen (IV) monomer}

Figure $3 \mathrm{~A}$ schematic drawing that illustrates the structural features of a functional collagen (IV) monomer, comprising three collagen chains. Studies have shown that a functional collagen (IV) monomer is a trimeric structure, comprising either $\alpha 1, \alpha 2, \alpha 3, \alpha 4, \alpha 5$ or $\alpha 6$, which can be a homotrimeric or a heterotrimeric structure. Each collagen $\alpha$ chain, such as collagen $\alpha 3$ (IV) has an $\mathrm{N}$-terminal non-collagenous $7 \mathrm{~S}$ domain of $\sim 15$ amino acid residues behind the signal peptide, a middle collagenous domain of $\sim 1,400$ residues of GXY repeats, and a C-terminal non-collagenous (NC1) domain of $\sim 230$ amino acid residues, which is also the domain that was shown to be biologically active in the testis and also in other epithelia (see text for details).

cell exfoliation through changes in the organization of actin and MT cytoskeletons (Chen et al. 2017b). In fact, this unusual physiological activity of the NC1-peptide by perturbing the Sertoli BTB integrity in vivo was also found to perturb spermatogenic function, illustrating its potential use as a male contraceptive. However, much study is needed to unravel the underlying molecular mechanism by which the NC1-peptide perturbs the actin- and MT-based cytoskeletons to perturb basal ES/ BTB and apical ES function, in particular the downstream signaling protein(s) and pathway(s). This information is crucial to understand its physiological role to support spermatogenesis. Nonetheless, our findings regarding the biological function of NC1 peptide to modulate spermatogenic function are consistent with reports in the literature (Table 4). These other studies have illustrated biologically active fragments are also produced from collagen chains in tissues which also serve as regulatory peptides to modulate multiple cellular functions (Table 4).

\section{Role of LG3/4/5-peptide in junction dynamics in the testis}

Studies have shown that besides type IV collagen, laminin $\alpha 1, \alpha 2, \alpha 4, \beta 1, \beta 2$, and $\gamma 1$ chains are constituent components of the basement membrane, surrounding the base of seminiferous tubules in rodent testes (Koch et al. 1999, Häger et al. 2005). Interestingly, few reports are found in the literature that examine the physiological role of these laminin chains residing in the basement membrane in supporting spermatogenic function except for their structural roles in the testis (Virtanen et al. 1997, Aydos et al. 1998). In an earlier report using a genetic model wherein transgenic mice deficient in laminin $\alpha 2$ chain (also known as merosin) were found to be infertile, and their seminiferous tubules were devoid of germ cells due to apical ES disruption, which, in turn, led to germ cell exfoliation (Häger et al. 2005). Also, a disruption of laminin function in the basement membrane by passive immunization of anti-laminin IgG to guinea pigs was found to induce spermatogenesis arrest (Lustig et al. 2000). Collectively, these reports illustrate the biological significance of basement membrane laminin chains in supporting spermatogenic function. Furthermore, there are reports in the literature illustrating that biologically active fragments are generated from laminin chains via the action of MMPs which can modulate multiple cellular functions including cell adhesion, vascular permeability, cell apoptosis, cell proliferation and cell differentiation in multiple epithelia, tissues and organs other than the testis (Sato et al. 1994, Yan et al. 2007, Tang and Saito 2018a,b) (Table 2). We thus sought to examine if laminin $\alpha 2$ chain in the basement membrane would have similar biological effects on Sertoli cell BTB and spermatogenic function in the testis. As noted in Fig. 4, laminin $\alpha 2$ chain consists of an laminin $\mathrm{N}$-terminal domain (LN) to be followed by two laminin 4a domain (L4a) and laminin 4b domain (L4b) interspaced with the laminin EGF-like domain a (LEa), LEb, and LEC an a long laminin coiled-coil (LCC) domain and five short C-terminal laminin globular (LG) domains at the C-terminus. Interestingly, using an in-house prepared antibody specific to the $80 \mathrm{kDa}$ fragment (Wong and Cheng 2013) and two additional commercially available anti-laminin antibodies, we have shown that an $80 \mathrm{kDa}$ 
Table 3 Selected mouse models of deletion of collagen chains and the associated phenotypes.

\begin{tabular}{|c|c|c|c|c|}
\hline Collagen chain & Mouse model & Approach & Phenotypes & References \\
\hline Collagen $\alpha 3$ (IV) & $\begin{array}{l}\text { Mice with a targeted } \\
\text { deletion encoding the } \\
\text { NC1 domain of the Col } 4 \alpha 3 \\
\text { gene }\end{array}$ & Deletion of the Col $4 \alpha 3$ gene & $\begin{array}{l}\text { Renal failure due to lack of } \\
\text { collagen } \alpha 3 \alpha 4 \alpha 5 \text { (IV) networks } \\
\text { but retention of collagen } \alpha 1 \alpha 2 \alpha 1 \\
\text { networks in kidney glomerular } \\
\text { basement membrane }\end{array}$ & $\begin{array}{l}\text { Steenhard et al. } \\
2012\end{array}$ \\
\hline Collagen $\alpha 2(\mathrm{~V})$ & Mice with Col $5 \alpha 2$ knockout & $\begin{array}{l}\text { Tamoxifen-induced whole } \\
\text { body Col5a2 gene } \mathrm{KO}\end{array}$ & $\begin{array}{l}\text { Skin and adipose abnormalities } \\
\text { such as skin thinking and marked } \\
\text { loss of dermal white adipose tissue } \\
\text { (WAT) and abdominal WAT, and } \\
\text { vascular defects including aortic } \\
\text { aneurysm and dissection }\end{array}$ & Park et al. 2017 \\
\hline Collagen $\alpha 1(\mathrm{~V})$ & $\begin{array}{l}\text { Targeted tendon and } \\
\text { ligament Col5 } \alpha 1 \text {-null } \\
\text { mouse model }\end{array}$ & $\begin{array}{l}\text { Targeted deletion of collagen } \\
\alpha 1(\mathrm{~V}) \text { in tendons and } \\
\text { ligaments }\end{array}$ & $\begin{array}{l}\text { Reduced body size, grip weakness, } \\
\text { and early onset of osteoarthritis; } \\
\text { abnormal joint phenotypes with } \\
\text { reduced collagen fibrils in joint } \\
\text { stabilizing ligaments and tendons }\end{array}$ & Sun et al. 2015 \\
\hline Collagen $\alpha 1(\mathrm{VI})$ & Col6 $\alpha 1$ null mice & $\begin{array}{l}\text { Mouse whole body Col6a1 } \\
\text { gene KO }\end{array}$ & $\begin{array}{l}\text { Reduced tensile strength of the skin, } \\
\text { and reduced biomechanical } \\
\text { strength and stiffness of tendons } \\
\text { due to abnormal collagen I fibrils. } \\
\text { Collagen VI deficiency led to } \\
\text { disruptive changes in matrix } \\
\text { architecture and biomechanical } \\
\text { properties }\end{array}$ & $\begin{array}{l}\text { Lettmann et al. } \\
2014\end{array}$ \\
\hline $\begin{array}{l}\text { Collagen } \alpha 1(\mathrm{XXV}) \text { also } \\
\text { known as CLAC-P/ } \\
\text { collagen XXV }\end{array}$ & Col25 $\alpha 1$-deficient (KO) mice & $\begin{array}{l}\text { Mouse whole body Col25a1 } \\
\text { gene KO }\end{array}$ & $\begin{array}{l}\text { Col25 } 1 \text { mice died immediately } \\
\text { after birth due to respiratory } \\
\text { failure. Motor axons projected to } \\
\text { target muscles but failed to } \\
\text { elongate and branch within the } \\
\text { muscle, to be followed by axon } \\
\text { degeneration }\end{array}$ & $\begin{array}{l}\text { Tanaka et al. } \\
2014\end{array}$ \\
\hline
\end{tabular}

fragment of laminin $\alpha 2$ chain containing the LG domains generated at the basement membrane, likely through proteolytical cleavage of MMP9, is detected at the apical ES (Gao et al. 2017b). A study using taxol (also known as paclitaxel, an anti-mitotic drug, which binds to ß-tubulin by inhibiting MT growth through hyperstabilization of MTs, depleting the plasticity of MTs to support changes in cell shape and function to confer cellular homeostasis (Press et al. 2019)) has shown that this $80 \mathrm{kDa}$ fragment from the C-terminal region of laminin- $\alpha 2$ chain (i.e., LG3/4/5-fragment) is being transported from the basement membrane to the apical ES site through an MT-dependent transport mechanism (Gao et al. 2017b). This observation is important because it supports the notion that a biologically active fragment can likely be generated from laminin- $\alpha 2$ chain in the basement membrane, which is then transported to the apical ES site to exert its regulating effects. Interestingly using a siRNA specific to laminin- $\alpha 2$ chain cloned into pGene-Clip hMGFP vector for laminin- $\alpha 2$ knockdown by transfecting Sertoli cell epithelium cultured in vitro with this clone, it was found to perturb the Sertoli cell TJ-permeability function by disrupting the organization of actin filaments and MTs across the cell cytosol. These findings thus support the notion that laminin- $\alpha 2$ chain is being used to promote Sertoli cell TJ-barrier function in the testis in vivo under physiological conditions. Interestingly, in a follow-up study, it was shown that

Table 4 Biological activities of collagen chains and their fragments in selected study models.

\begin{tabular}{|c|c|c|c|}
\hline $\begin{array}{l}\text { Collagen ligand/chain (or } \\
\text { fragments) }\end{array}$ & Animal/cell types & Biological effects & References \\
\hline Collagen $\alpha 2$ (I) (COL1A2) & $\begin{array}{l}\text { Chondrosarcoma and } \\
\text { fibrosarcoma cells }\end{array}$ & $\begin{array}{l}\text { Mediates the pro- and anti-migratory effects of TBX3 } \\
\text { (T-box transcription factor } 3 \text { ) in cells }\end{array}$ & Omar et al. 2019 \\
\hline Collagen VI fragments & Epithelial and endothelial cells & Maintains epithelial andendothelial cell polarity & $\begin{array}{l}\text { Willumsen et al. } \\
2019\end{array}$ \\
\hline T3 peptide from collagen $\alpha 3$ (IV) & Rats & $\begin{array}{l}\text { Exerts cardio-protective effects against ischemia/ } \\
\text { reperfusion injury in heart }\end{array}$ & Yasuda et al. 2019 \\
\hline T3 peptide from collagen $\alpha 3$ (IV) & Cardiac fibroblasts & $\begin{array}{l}\text { Stimulates proliferation and migration of cardiac } \\
\text { fibroblasts }\end{array}$ & Yasuda et al. 2017 \\
\hline $\begin{array}{l}\text { Collagen } \alpha 1(\mathrm{XI}) \text { chain } \\
\text { (COL11A1) }\end{array}$ & Tumor and stromal cells & $\begin{array}{l}\text { Overexpression of COL11A1 induces malignancies } \\
\text { and aggressive tumor cell behavior }\end{array}$ & Toss et al. 2019 \\
\hline $\begin{array}{l}\text { Endostatin (C-terminal } 20 \mathrm{kDa} \\
\text { fragment of collagen XVIII) }\end{array}$ & Humans & $\begin{array}{l}\text { Inhibitors of angiogenesis, lymphangiogenesis, and } \\
\text { cancer metastasis }\end{array}$ & Walia et al. 2015 \\
\hline
\end{tabular}




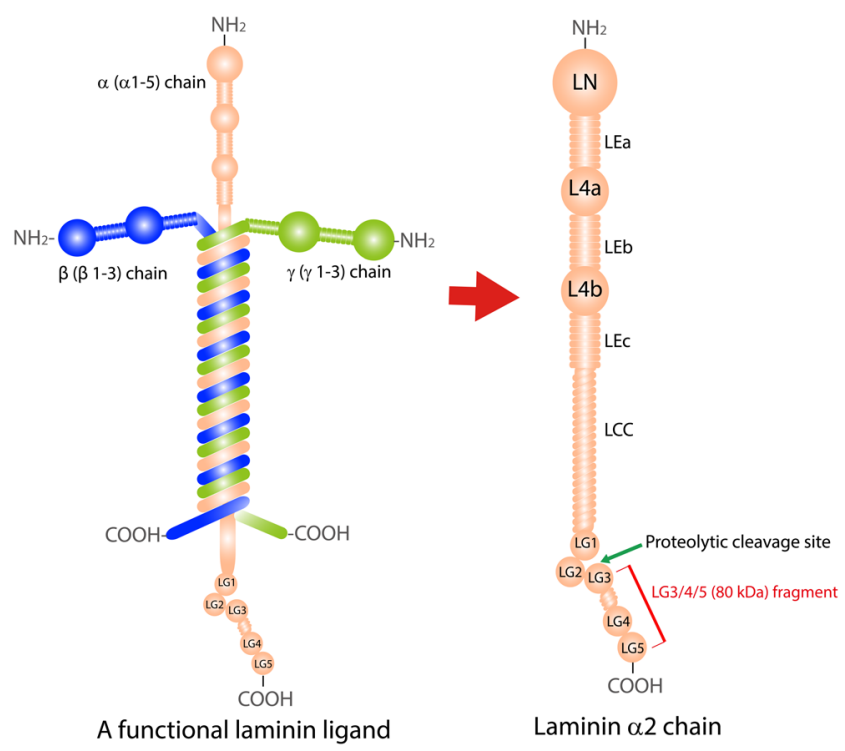

Figure $4 \mathrm{~A}$ schematic drawing that illustrates the structural features of laminin- $\alpha 2$ chain and the functional laminin- $\alpha 2$-based ligand. The left panel shows the structural features of the laminin- $\alpha 2$-based laminin ligand found in the basement membrane of rat testes. A functional laminin ligand is also a trimeric structure, composed of three chains, one chain each of the $\alpha$ (from $\alpha 1$ to $\alpha 5$ ), $\beta$ (from $\beta 1$ to B3) and $\gamma$ (from $\gamma 1$ to $\gamma 3$ ) chains. The right panel is the detailed structural domain of laminin- $\alpha 2$ chain. From the $\mathrm{N}$-terminus, three distinctive globular domains of (i) laminin N-terminal domain (LN), (ii) L4a (laminin 4a domain) and (iii) L4b (laminin 4b domain) are noted. There are also three rod domains of epidermal growth factor (EGF): (i) LEa (laminin EGF-like domain a), (ii) LEb (laminin EGF-like domain b) and LEc (laminin EGF-like domain c). The long arm of laminin- $\alpha 2$ is comprised of laminin coiled-coil (LCC) domain and 5 C-terminal laminin globular (LG) domains of LG1, LG2, LG3, LG4 and LG5. There is a putative proteolytic cleavage site close to the $\mathrm{N}$-terminus of LG3, and its cleavage by MMP-9 thus generate the LG3/4/5, corresponding to the $80 \mathrm{kDa}$ laminin- $\alpha 2$ fragment that has the biological activity of promoting BTB integrity and possibly spermatogenic function in the testis (see text for details).

a silencing of laminin- $\alpha 2$ by RNAi to perturb Sertoli cell TJ function by disrupting distribution of TJ- and basal ES proteins at the cell-cell interface involved an activation of mTORC1/rpS6 (Gao et al. 2017a). For instance, an upregulation on the protein steady-state levels of p-rpS6-S235/S236 and p-rpS6-S240/S244 (the activated phosphorylated form of rpS6, which is also the downstream signaling protein of mTORC1 and a phosphorylatable protein translation regulator (Laplante and Sabatini 2012, Meyuhas 2015)) and a concomitant downregulation of p-Akt1-S473 and p-Akt2-S474, were detected (Gao et al. 2017a). These findings thus indicate that the laminin- $\alpha 2$ chain, most likely through the LG3/4/5-peptide, promotes BTB and spermatogenic function through the mTORC1/rpS6 and Akt1/2 signaling pathway downstream. In this context, it is of interest to note that mTORC1/rpS6 and Akt1/2 signaling pathway has been shown to be involved in regulating $\mathrm{BTB}$ and spermatogenic function in the testis (Mok et al. 2012). For instance, an activation of mTORC1/rpS6, such as through the use of a quadruple phosphomimetic (i.e. constitutively active) mutant of rpS6 namely p-rpS6-mutant (i.e, p-rpS6-S235E/S236E and p-rpS6-S240E/S244E quadruple phosphomimetic mutant) was found to induce Sertoli BTB disruption in vitro (Mok et al. 2014, 2015) and in vivo (Li et al. 2018). Nonetheless, the precise molecular mechanism, in particular, the involvement of the mTORC1/rpS6/ Akt1/2 signaling pathway in LG3/4/5-peptide-mediated BTB and spermatogenic function, requires investigation in future studies.

\section{A hypothetical model by which the endogenously bioactive peptides support spermatogenesis}

Based on findings summarized above, it is notable that F5- and NC1-peptides induce BTB remodeling at the basal ES to support the transport of preleptotene spermatocytes across the immunological barrier (Fig. 5). At the same time, these two peptides also support apical ES degeneration to facilitate sperm release at spermiation (Fig. 5). Thus, the biological activity of these two peptide are crucial to coordinate these two cellular events that take place at the opposite ends of the seminiferous epithelium at stage VIII of the epithelial cycle, namely (i) BTB remodeling near the base of the epithelium to support preleptotene spermatocytes at the basal compartment to be transported across the BTB to enter the adluminal compartment to prepare for meiosis and (ii) spermiation (Fig. 5). On the other hand, the LG3/4/5-peptide is crucial to promote basal ES integrity and BTB assembly such as the 'new' BTB that required to be assembled behind the preleptotene spermatocytes under transport as noted in Fig. 5. Furthermore, LG3/4/5-peptide also promotes apical ES assembly when step 8 spermatids appear in stage VIII tubules (Fig. 5). In short, it is through the concerted effects of F5- and NC1-peptides, and their contrasting effects with the LG3/4/5-peptide, different cellular events that take place simultaneously across the seminiferous epithelium can be coordinated throughout the epithelial cycle of spermatogenesis (Fig. 5). It is obvious that the hypothetical model depicted in Fig. 5 will be updated in the years to come when more information is available, but this model provides a framework upon which experiments can be designed to examine the role of these regulating peptides in the testis to support spermatogenesis.

\section{Concluding remarks and future perspectives}

As briefly reviewed herein, it is increasingly clear that the constituent components at the ES and the BM including both laminin and collagen chains are more than just proteins that provide structural support to the ES and BM. Besides their scaffolding role, locally expressed MMPs, such as MMP2 and MMP9 at the 

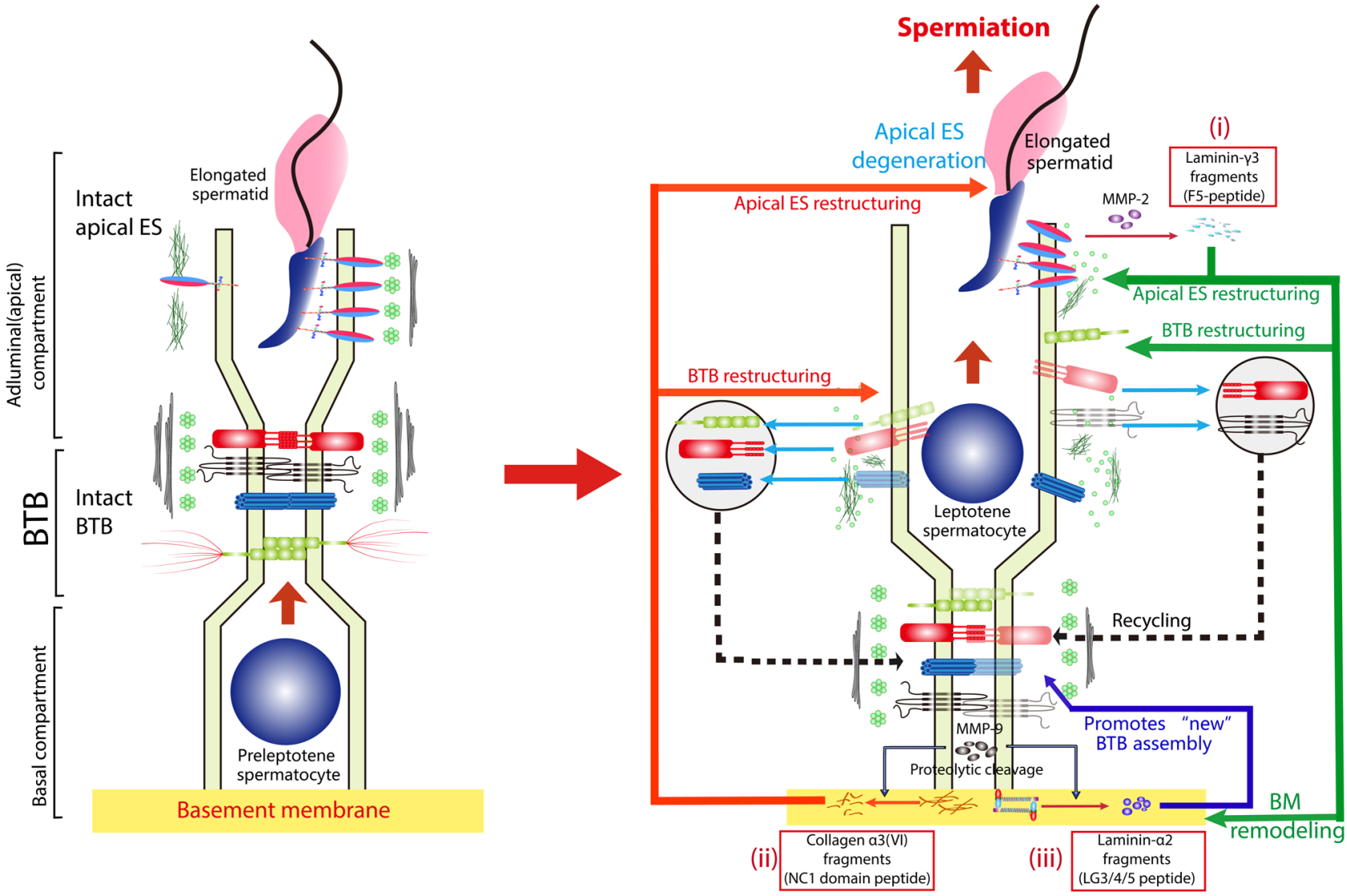
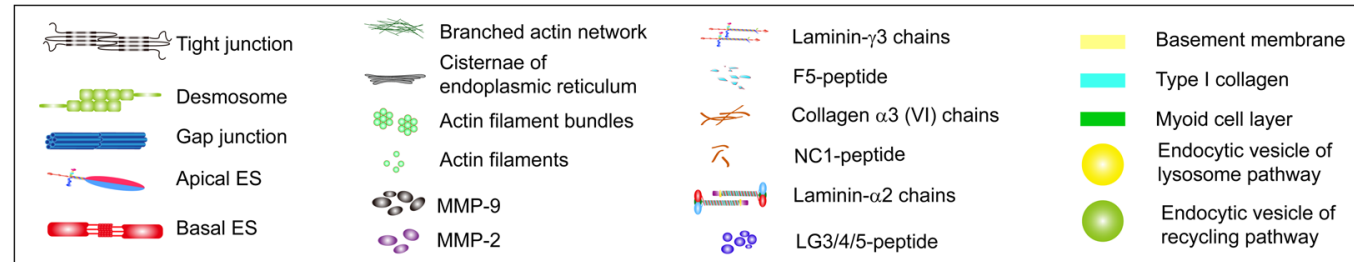

Figure 5 A hypothetical model that illustrates the three endogenously produced biologically active peptides that modulate junction remodeling events to support spermatogenesis during the epithelial cycle across the seminiferous epithelium. On the left panel, it is a schematic drawing that illustrates a stage VII tubule, whereas the right panel illustrates a stage VIII tubule. The production of (i) the F5-peptide from laminin- $\gamma 3$ chains, and (ii) the NC1-peptide from collagen $\alpha 3$ (IV) chains promote BTB remodeling and apical ES degeneration to facilitate the transport of preleptotene spermatocytes across the immunological barrier and the release of sperm at spermation, respectively. The production of (iii) the LG3/4/5-peptide from laminin- $\alpha 2$ chains promotes BTB integrity by facilitating the assembly of the 'new' BTB that forms behind the preleptene spermatocytes while transforming into leptotene spermatocytes. Thus, the BTB remains 'intact' throughout the epithelial cycle even when preleptotene spermatocytes are being transported across the immunological barrier (see text for details).

apical ES and BM, can induce proteolytic cleavage to generate different biologically fragments to modulate cellular function locally, such as changes in junction permeability, cytoskeletal organization, and even distribution of regulatory proteins of the actin- and/or MT-based cytoskeletons at different stages of the epithelial cycle. This thus provides an efficient local mechanism to modulate different aspects of spermatogenic function in response to changes in the epithelial cycle of spermatogenesis as summarized in the hypothetic model depicted in Fig. 5. It is anticipated that this model will be updated in the years to come. Nonetheless, this model provides a working framework for investigators in the field. In this context, it is of interest to note that since Rap1 GTPase, based on studies using genetic models, has shown to play a central role in regulating spermatid adhesion and maintaining apical ES integrity in the seminiferous epithelium through the epithelial cycle in vivo via its effects on cell adhesion complexes at the apical ES, such as VE-cadherin, nectin 3 and JAM-C (Aivatiadou et al. 2007, 2009, Berruti and Paiardi 2014, Berruti et al. 2018), it is likely that Rap1 is working in concert with these bioactive peptides. This possibility should be carefully evaluated in future investigation 
since both Rap1 and the three bioactive peptides exert their regulatory effects through changes in the organization of F-actin and/or MT-based cytoskeletons.

\section{Declaration of interest}

The authors declare that there is no conflict of interest that could be perceived as prejudicing the impartiality of this review.

\section{Funding}

This work was supported in part by grants from the National Institutes of Health (NICHD, R01 HD056034 to CY C); National Natural Science Foundation of China (Grants 81971367 to L L, 81730042 to R G); and Department of Science and Technology of Zhejiang Province (Grant 2019C03035 to R G).

\section{Author contribution statement}

C Y C conceived the project and wrote the paper. H L, S L, $S W$, and $L L$ researched on the topics and searched for relevant information in the literature at www.PubMed.com which were discussed in this review. $\mathrm{HL}$ and $\mathrm{C} Y \mathrm{C}$ prepared the Tables. $\mathrm{HL}$ and $\mathrm{C} \mathrm{Y} \mathrm{C} \mathrm{prepared} \mathrm{the} \mathrm{figures.} \mathrm{H} \mathrm{L}, \mathrm{S} L, S W, L L$ and $\mathrm{R}$ $\mathrm{G}$ discussed the concepts evaluated in this review. All authors read and approved the final manuscript.

\section{References}

Ackley BD, Crew JR, Elamaa H, Pihlajaniemi T, Kuo CJ \& Kramer JM 2001 The NC1/endostatin domain of Caenorhabditis elegans type XVIII collagen affects cell migration and axon guidance. Journal of Cell Biology 152 1219-1232. (https://doi.org/10.1083/jcb.152.6.1219)

Aivatiadou E, Mattei E, Ceriani M, Tilia L \& Berruti G 2007 Impaired fertility and spermiogenetic disorders with loss of cell adhesion in male mice expressing an interfering Rap1 mutant. Molecular Biology of the Cell 18 1530-1542. (https://doi.org/10.1091/mbc.e06-10-0902)

Aivatiadou E, Ripolone M, Brunetti F \& Berruti G 2009 cAMP-Epac2mediated activation of Rap1 in developing male germ cells: RA-RhoGAP as a possible direct down-stream effector. Molecular Reproduction \& Development 76 407-416. (https://doi.org/10.1002/mrd.20963)

Albrengues J, Shields MA, Ng D, Park CG, Ambrico A, Poindexter ME, Upadhyay P, Uyeminami DL, Pommier A, Kuttner V, et al. 2018 Neutrophil extracellular traps produced during inflammation awaken dormant cancer cells in mice. Science 361 eaao4227. (https://doi. org/10.1126/science.aao4227)

Assadian S \& Teodoro JG 2008 Regulation of collagen-derived antiangiogenic factors by p53. Expert Opinion on Biological Therapy 8 941-950. (https://doi.org/10.1517/14712598.8.7.941)

Aydos K, Soygur T, Kupeli B, Unsal A, Tolunary O, Erdem E, Guven C \& Kupeli S 1998 Testicular effects of vasectomy in rats: an ultrastructural and immunohistochemical study. Urology 51 1051-1056. (https://doi. org/10.1016/s0090-4295(98)00100-9)

Barczyk M, Carracedo S \& Gullberg D 2010 Integrins. Cell \& Tissue Research 339 269-280. (https://doi.org/10.1007/s00441-009-0834-6)

Berruti G \& Paiardi C 2014 The dynamic of the apical ectoplasmic specialization between spermatids and Sertoli cells: the case of the small GTPase Rap1. BioMed Research International 2014 635979. (https://doi. org/10.1155/2014/635979)

Berruti G, Ceriani M \& Martegani E 2018 Dynamic of VE-cadherinmediated spermatid-Sertoli cell contacts in the mouse seminiferous epithelium. Histochemistry \& Cell Biology 150 173-185. (https://doi. org/10.1007/s00418-018-1682-9)
Chen H, Gao Y, Mruk DD, Xiao X, John CM, Turek PJ, Lui WY, Lee WM, Silvestrini B \& Cheng CY 2017a Rescue of PFOS-induced human Sertoli cell injury by overexpressing a p-FAK-Y407E phosphomimetic mutant. Scientific Reports 7 15810. (https://doi.org/10.1038/s41598-017-15671-4)

Chen H, Mruk DD, Lee WM \& Cheng CY 2017b Regulation of spermatogenesis by a local functional axis in the testis: role of the basement membrane-derived noncollagenous 1 domain peptide. FASEB Journal 31 3587-3607. (https://doi.org/10.1096/fj.201700052R)

Chen H, Mruk D, Wong CKC, Silvestrini B \& Cheng CY 2019 F5-peptide enhances the efficacy of the non-hormonal male contraceptive adjudin. Contraception 99 350-356. (https://doi.org/10.1016/j. contraception.2019.01.007)

Cheng CY \& Mruk DD 2002 Cell junction dynamics in the testis: Sertoligerm cell interactions and male contraceptive development. Physiological Reviews 82 825-874. (https://doi.org/10.1152/physrev.00009.2002)

Cheng CY \& Mruk DD 2010 A local autocrine axis in the testes that regulates spermatogenesis. Nature Reviews. Endocrinology 6 380-395. (https://doi.org/10.1038/nrendo.2010.71)

Cheng CY \& Mruk DD 2012 The blood-testis barrier and its implication in male contraception. Pharmacological Reviews 64 16-64. (https://doi. org/10.1124/pr.110.002790)

Cheng CY \& Mruk DD 2015 Biochemistry of Sertoli cell/germ cell junctions, germ cell transport, and spermiation in the seminiferous epithelium. In Sertoli Cell Biology, 2nd ed. Ed. MD Griswold. Amsterdam: Elsevier, pp. 333-383. (https://doi.org/10.1016/B978-0-12-417047-6.00012.0)

Cheng CY, Mruk DD, Silvestrini B, Bonanomi M, Wong CH, Siu MK, Lee NP, Lui WY \& Mo MY 2005 AF-2364 [1-(2,4-dichlorobenzyl)-1Hindazole-3-carbohydrazide] is a potential male contraceptive: a review of recent data. Contraception 72 251-261. (https://doi.org/10.1016/j. contraception.2005.03.008)

Clermont Y 1972 Kinetics of spermatogenesis in mammals: seminiferous epithelium cycle and spermatogonial renewal. Physiological Reviews $\mathbf{5 2}$ 198-236. (https://doi.org/10.1152/physrev.1972.52.1.198)

de Kretser DM \& Kerr JB 1988 The cytology of the testis. In The Physiology of Reproduction 1. E Knobil, JB Neill, LL Ewing, GS Greenwald, CL Markert \& DW Pfaff Eds. New York: Raven Press, pp. 837-932.

Dym M 1994 Basement membrane regulation of Sertoli cells. Endocrine Reviews 15 102-115. (https://doi.org/10.1210/edrv-15-1-102)

Fleger-Weckmann A, Ustun Y, Kloepper J, Paus R, Bloch W, Chen ZL, Wegner J, Sorokin L, Langbein L, Eckes B, et al. 2016 Deletion of the epidermis derived laminin gamma1 chain leads to defects in the regulation of late hair morphogenesis. Matrix Biology 56 42-56. (https:// doi.org/10.1016/j.matbio.2016.05.002)

Franca LR, Auharek SA, Hess RA, Dufour JM \& Hinton BT 2012 Bloodtissue barriers: morphofunctional and immunological aspects of the blood-testis and blood-epididymal barriers. Advances in Experimental Medicine \& Biology 763 237-259. (https://doi.org/10.1007/978-1-46144711-5_12)

Gao Y, Mruk DD, Lui WY, Lee WM \& Cheng CY 2016 F5-peptide induces aspermatogenesis by disrupting organization of actin- and microtubulebased cytoskeletons in the testis. Oncotarget 7 64203-64220. (https:// doi.org/10.18632/oncotarget.11887)

Gao Y, Chen H, Lui WY, Lee WM \& Cheng CY 2017a Basement membrane laminin $\alpha 2$ regulation of BTB dynamics via its effects on F-actin and microtubule (MT) cytoskeletons is mediated through mTORC1 signaling. Endocrinology 158 963-978. (https://doi.org/10.1210/en.2016-1630)

Gao Y, Mruk D, Chen H, Lui WY, Lee WM \& Cheng CY 2017b Regulation of the blood-testis barrier by a local axis in the testis: role of laminin $\alpha 2$ in the basement membrane. FASEB Journal 31 584-597. (https://doi. org/10.1096/fj.201600870R)

Gliki G, Ebnet K, Aurrand-Lions M, Imhof BA \& Adams RH 2004 Spermatid differentiation requires the assembly of a cell polarity complex downstream of junctional adhesion molecule-C. Nature 431 320-324. (https://doi.org/10.1038/nature02877)

Gopal SK, Greening DW, Zhu HJ, Simpson RJ \& Mathias RA 2016 Transformed MDCK cells secrete elevated MMP1 that generates LAMA5 fragments promoting endothelial cell angiogenesis. Scientific Reports 6 28321. (https://doi.org/10.1038/srep28321)

Hadley MA \& Dym M 1987 Immunocytochemistry of extracellular matrix in the lamina propia of the rat testis: electron microscopic localization. Biology of Reproduction 37 1283-1289. (https://doi.org/10.1095/ biolreprod37.5.1283) 
Häger M, Gawlik K, Nyström A, Sasaki T \& Durbeej M 2005 Laminin $\alpha 1$ chain corrects male infertility caused by absence of laminin $\alpha 2$ chain American Journal of Pathology 167 823-833. (https://doi.org/10.1016/ s0002-9440(10)62054-8)

Hamano Y \& Kalluri R 2005 Tumstatin, the NC1 domain of $\alpha 3$ chain of type IV collagen, is an endogenous inhibitor of pathological angiogenesis and suppresses tumor growth. Biochemical \& Biophysical Research Communications 333 292-298. (https://doi.org/10.1016/j. bbrc.2005.05.130)

Heller CG \& Clermont Y 1963 Spermatogenesis in man: an estimate of its duration. Science $\mathbf{1 4 0} 184-186$. (https://doi.org/10.1126/ science.140.3563.184)

Hermo L, Pelletier RM, Cyr DG \& Smith CE 2010a Surfing the wave, cycle, life history, and genes/proteins expressed by testicular germ cells. Part 1: background to spermatogenesis, spermatogonia, and spermatocytes. Microscopy Research \& Technique 73 241-278. (https://doi.org/10.1002/ jemt.20783)

Hermo L, Pelletier RM, Cyr DG \& Smith CE $2010 b$ Surfing the wave, cycle, life history, and genes/proteins expressed by testicular germ cells. Part 4: intercellular bridges, mitochondria, nuclear envelope, apoptosis, ubiquitination, membrane/voltage-gated channels, methylation acetylation, and transcription factors. Microscopy Research \& Technique 73 364-408. (https://doi.org/10.1002/jemt.20785)

Hermo L, Pelletier RM, Cyr DG \& Smith CE 2010c Surfing the wave, cycle, life history, and genes/proteins expressed by testicular germ cells. Part 5: intercellular junctions and contacts between germ cells and Sertoli cells and their regulatory interactions, testicular cholesterol, and genes/ proteins associated with more than one germ cell generation. Microscopy Research \& Technique 73 409-494. (https://doi.org/10.1002/jemt.20786)

Hess RA \& de Franca LR 2008 Spermatogenesis and cycle of the seminiferous epithelium. Advances in Experimental Medicine \& Biology 636 1-15. (https://doi.org/10.1007/978-0-387-09597-4_1)

Horejs CM, Serio A, Purvis A, Gormley AJ, Bertazzo S, Poliniewicz A, Wang AJ, DiMaggio P, Hohenester E \& Stevens MM 2014 Biologicallyactive laminin-111 fragment that modulates the epithelial-tomesenchymal transition in embryonic stem cells. PNAS 111 5908-5913. (https://doi.org/10.1073/pnas.1403139111)

Hudson BG, Reers ST \& Tryggvason K 1993 Type IV collagen: structure, gene organization, and role in human diseases. Molecular basis of Goodpasture and Alport syndromes and diffuse leiomyomatosis. Journal of Biological Chemistry 268 26033-26036.

Inagaki M, Irie K, Ishizaki H, Tanaka-Okamoto $M$, Miyoshi J \& Takai Y 2006 Role of cell adhesion molecule nectin-3 in spermatid development. Genes to Cells: Devoted to Molecular \& Cellular Mechanisms 11 11251132. (https://doi.org/10.1111/j.1365-2443.2006.01006.x)

Jenkins MH, Alrowaished SS, Goody MF, Crawford BD \& Henry CA 2016 Laminin and matrix metalloproteinase 11 regulate fibronectin levels in the zebrafish myotendinous junction. Skeletal Muscle 6 18. (https://doi. org/10.1186/s13395-016-0089-3)

Kamoshida G, Ogawa T, Oyanagi J, Sato H, Komiya E, Higashi S, Miyazaki K \& Tsuji T 2014 Modulation of matrix metalloproteinase-9 secretion from tumor-associated macrophage-like cells by proteolytically processed laminin-332 (laminin-5). Clinical \& Experimental Metastasis 31285 291. (https://doi.org/10.1007/s10585-013-9627-0)

Kikkawa Y, Hozumi K, Katagiri F, Nomizu M, Kleinman HK \& Koblinski JE 2013 Laminin-111-derived peptides and cancer. Cell Adhesion \& Migration 7 150-256. (https://doi.org/10.4161/cam.22827)

Koch M, Olson PF, Albus A, Jin W, Hunter DD, Brunken WJ, Burgeson RE \& Champliaud MF 1999 Characterization and expression of the laminin $\gamma 3$ chain: a novel, non-basement membrane-associated, laminin chain. Journal of Cell Biology 145 605-618. (https://doi.org/10.1083/ jcb.145.3.605)

Laplante M \& Sabatini DM 2012 MTOR signaling in growth control and disease. Cell 149 274-293. (https://doi.org/10.1016/j.cell.2012.03.017)

Lettmann S, Bloch W, Maass T, Niehoff A, Schulz JN, Eckes B, Eming SA, Bonaldo P, Paulsson M \& Wagener R 2014 Col6a1 null mice as a model to study skin phenotypes in patients with collagen $\mathrm{VI}$ related myopathies: expression of classical and novel collagen VI variants during wound healing. PLOS ONE 9 e105686. (https://doi.org/10.1371/journal. pone.0105686)

Li SYT, Yan M, Chen H, Jesus TT, Lee WM, Xiao X \& Cheng CY 2018 mTORC1/rpS6 regulates blood-testis barrier (BTB) dynamics and spermatogenetic function in the testis in vivo. American Journal of Physiology. Endocrinology \& Metabolism 314 E174-E190. (https://doi. org/10.1152/ajpendo.00263.2017)

Lian G, Miller KA \& Enders GC 1992 Localization and synthesis of entactin in seminiferous tubules of the mouse. Biology of Reproduction 47316 325. (https://doi.org/10.1095/biolreprod47.3.316)

Libby RT, Lavallee CR, Balkema GW, Brunken WJ \& Hunter DD 1999 Disruption of laminin beta2 chain production causes alterations in morphology and function in the CNS. Journal of Neuroscience 199399 9411. (https://doi.org/10.1523/JNEUROSCI.19-21-09399.1999)

Lie PPY, Mruk DD, Mok KW, Su L, Lee WM \& Cheng CY 2012 Focal adhesion kinase-Tyr407 and -Tyr397 exhibit antagonistic effects on blood-testis barrier dynamics in the rat. PNAS 109 12562-12567. (https://doi.org/10.1073/pnas.1202316109)

Lin X 2004 Functions of heparan sulfate proteoglycans in cell signaling during development. Development 131 6009-6021. (https://doi. org/10.1242/dev.01522)

Lustig L, Denduchis B, Ponzio R, Lauzon MP \& Pelletier RM 2000 Passive immunization with anti-laminin immunoglobulin $\mathrm{G}$ modifies the integrity of the seminiferous epithelium and induces arrest of spermatogenesis in the guinea pig. Biology of Reproduction 62 1505-1514. (https://doi. org/10.1095/biolreprod62.6.1505)

Meyuhas O 2015 Ribosomal protein S6 phosphorylation: four decades of research. International Review of Cell \& Molecular Biology 320 41-73. (https://doi.org/10.1016/bs.ircmb.2015.07.006)

Mital P, Hinton BT \& Dufour JM 2011 The blood-testis and blood-epididymis barriers are more than just their tight junctions. Biology of Reproduction 84 851-858. (https://doi.org/10.1095/biolreprod.110.087452)

Mok KW, Mruk DD, Silvestrini B \& Cheng CY 2012 rpS6 regulates bloodtestis barrier dynamics by affecting F-actin organization and protein recruitment. Endocrinology 153 5036-5048. (https://doi.org/10.1210/ en.2012-1665)

Mok KW, Mruk DD \& Cheng CY 2014 rpS6 regulates blood-testis barrier dynamics through Akt-mediated effects on MMP-9. Journal of Cell Science 127 4870-4882. (https://doi.org/10.1242/jcs.152231)

Mok KW, Chen H, Lee WM \& Cheng CY 2015 rpS6 regulates bloodtestis barrier dynamics through Arp3-mediated actin microfilament organization in rat Sertoli cells. An in vitro study. Endocrinology 156 1900-1913. (https://doi.org/10.1210/en.2014-1791)

Mruk DD \& Cheng CY 2004 Sertoli-Sertoli and Sertoli-germ cell interactions and their significance in germ cell movement in the seminiferous epithelium during spermatogenesis. Endocrine Reviews 25 747-806. (https://doi.org/10.1210/er.2003-0022)

Muciaccia B, Boitani C, Berloco BP, Nudo F, Spadetta G, Stefanini M, de Rooij DG \& Vicini E 2013 Novel stage classification of human spermatogenesis based on acrosome development. Biology of Reproduction 89 60. (https://doi.org/10.1095/biolreprod.113.111682)

Mulholland DJ, Dedhar S \& Vogl AW 2001 Rat seminiferous epithelium contains a unique junction (ectoplasmic specialization) with signaling properties both of cell/cell and cell/matrix junctions. Biology of Reproduction 64 396-407. (https://doi.org/10.1095/ biolreprod64.1.396)

O'Donnell L 2014 Mechanisms of spermiogenesis and spermiation and how they are disturbed. Spermatogenesis $\mathbf{4}$ e979623. (https://doi.org/10 .4161/21565562.2014.979623)

O'Donnell L, Nicholls PK, O'Bryan MK, McLachlan RI \& Stanton PG 2011 Spermiation: the process of sperm release. Spermatogenesis 1 14-35. (https://doi.org/10.4161/spmg.1.1.14525)

Omar R, Cooper A, Maranyane HM, Zerbini L \& Prince S 2019 COL1A2 is a TBX3 target that mediates its impact on fibrosarcoma and chondrosarcoma cell migration. Cancer Letters 459 227-239. (https:// doi.org/10.1016/j.canlet.2019.06.004)

Ortega N \& Werb Z 2002 New functional roles for noncollagenous domains of basement membrane collagens. Journal of Cell Science $\mathbf{1 1 5}$ 4201-4214. (https://doi.org/10.1242/jcs.00106)

Ozaki-Kuroda K, Nakanishi H, Ohta H, Tanaka H, Kurihara H, Mueller S, Irie K, Ikeda W, Sakai T, Wimmer E, et al. 2002 Nectin couples cellcell adhesion and the actin scaffold at heterotypic testicular junctions. Current Biology 12 1145-1150. (https://doi.org/10.1016/s09609822(02)00922-3)

Palombi F, Salanova M, Tarone G, Farini D \& Stefanini M 1992 Distribution of $\beta 1$ integrin subunit in rat seminiferous epithelium. 
Biology of Reproduction 47 1173-1182. (https://doi.org/10.1095/ biolreprod47.6.1173)

Park AC, Phan N, Massoudi D, Liu Z, Kernien JF, Adams SM, Davidson JM, Birk DE, Liu B \& Greenspan DS 2017 Deficits in Col5a2 expression result in novel skin and adipose abnormalities and predisposition to aortic aneurysms and dissections. American Journal of Pathology $\mathbf{1 8 7}$ 2300-2311. (https://doi.org/10.1016/j.ajpath.2017.06.006)

Pelletier RM 2011 The blood-testis barrier: the junctional permeability, the proteins and the lipids. Progress in Histochemistry \& Cytochemistry 46 49-127. (https://doi.org/10.1016/j.proghi.2011.05.001)

Pesch M, Konig S \& Aumailley M 2017 Targeted disruption of the Lama3 gene in adult mice is sufficient to induce skin inflammation and fibrosis. Journal of Investigative Dermatology 137 332-340. (https://doi. org/10.1016/j.jid.2016.07.040)

Press NJ, Joly E \& Ertl P 2019 Natural product drug delivery: a special challenge? Progress in Medicinal Chemistry 58 157-187. (https://doi. org/10.1016/bs.pmch.2019.01.001)

Radner S, Banos C, Bachay G, Li YN, Hunter DD, Brunken WJ \& Yee KT 2013 Beta2 and gamma3 laminins are critical cortical basement membrane components: ablation of Lamb2 and Lamc3 genes disrupts cortical lamination and produces dysplasia. Developmental Neurobiology 73 209-229. (https://doi.org/10.1002/dneu.22057)

Rebustini IT, Myers C, Lassiter KS, Surmak A, Szabova L, Holmbeck K, Pedchenko V, Hudson BG \& Hoffman MP 2009 MT2-MMP-dependent release of collagen IV NC1 domains regulates submandibular gland branching morphogenesis. Developmental Cell 17 482-493. (https://doi. org/10.1016/j.devcel.2009.07.016)

Salanova M, Stefanini M, De Curtis I \& Palombi F 1995 Integrin receptor $\alpha 6 \beta 1$ is localized at specific sites of cell-to-cell contact in rat seminiferous epithelium. Biology of Reproduction 52 79-87. (https://doi.org/10.1095/ biolreprod52.1.79)

Salanova M, Ricci G, Boitani C, Stefanini M, De Grossi S \& Palombi F 1998 Junctional contacts between Sertoli cells in normal and aspermatogenic rat seminiferous epithelium contain $\alpha 6 \beta 1$ integrins, and their formation is controlled by follicle-stimulating hormone. Biology of Reproduction 58 371-378. (https://doi.org/10.1095/biolreprod58.2.371)

Samuel MA, Valdez G, Tapia JC, Lichtman JW \& Sanes JR 2012 Agrin and synaptic laminin are required to maintain adult neuromuscular junctions. PLOS ONE 7 e46663. (https://doi.org/10.1371/journal. pone.0046663)

Sato F, Matsukawa Y, Matsumoto K, Nishino H \& Sakai T 1994 Apigenin induces morphological differentiation and G-2M arrest in rat neuronal cells. Biochemical \& Biophysical Research Communications 204578 584. (https://doi.org/10.1006/bbrc.1994.2498)

Setchell BP 2008 Blood-testis barrier, functional and transport proteins and spermatogenesis. Advances in Experimental Medicine \& Biology 636 212-233. (https://doi.org/10.1007/978-0-387-09597-4_12)

Silva EMR, Freitas VM, Bautz WG, de Barros LAP \& da Gama de Souza LN 2018 Immunohistochemical study of Laminin-332 gamma2 chain and MMP-9 in high risk of malignant transformation oral lesions and OSCC. Journal of Oral \& Maxillofacial Research 9 e3. (https://doi.org/10.5037/ jomr.2018.9103)

Siu MKY \& Cheng CY 2004a Dynamic cross-talk between cells and the extracellular matrix in the testis. BioEssays: News and Reviews in Molecular, Cellular and Developmental Biology 26 978-992. (https://doi. org/10.1002/bies.20099)

Siu MKY \& Cheng CY 2004b Interactions of proteases, protease inhibitors, and the $\beta 1$ integrin/laminin $\gamma 3$ protein complex in the regulation of ectoplasmic specialization dynamics in the rat testis. Biology of Reproduction 70945 964. (https://doi.org/10.1095/biolreprod.103.023606)

Siu MKY \& Cheng CY 2008 Extracellular matrix and its role in spermatogenesis. Advances in Experimental Medicine \& Biology 636 74-91. (https://doi.org/10.1007/978-0-387-09597-4_5)

Siu MKY, Lee WM \& Cheng CY 2003a The interplay of collagen IV, tumor necrosis factor- $\alpha$, gelatinase B (matrix metalloprotease-9), and tissue inhibitor of metalloprotease-1 in the basal lamina regulates Sertoli celltight junction dynamics in the rat testis. Endocrinology 144 371-387. (https://doi.org/10.1210/en.2002-220786)

Siu MKY, Mruk DD, Lee WM \& Cheng CY 2003b Adhering junction dynamics in the testis are regulated by an interplay of $\beta 1$-integrin and focal adhesion complex (FAC)-associated proteins. Endocrinology 144 2141-2163. (https://doi.org/10.1210/en.2002-221035)
Stanton PG 2016 Regulation of the blood-testis barrier. Seminars in Cell \& Developmental Biology 59 166-173. (https://doi.org/10.1016/j. semcdb.2016.06.018)

Steenhard BM, Vanacore R, Friedman D, Zelenchuk A, Stroganova L, Isom K, St John PL, Hudson BG \& Abrahamson DR 2012 Upregulated expression of integrin alpha 1 in mesangial cells and integrin alpha3 and vimentin in podocytes of Col4a3-null (Alport) mice. PLOS ONE 7 e50745. (https://doi.org/10.1371/journal.pone.0050745)

Su L, Mruk DD, Lie P, Silvestrini B \& Cheng CY 2012 A peptide derived from laminin $-\gamma 3$ reversibly impairs spermatogenesis in rats. Nature Communications 3 1185. (https://doi.org/1110.1038/ncomms2171)

Su L, Zhang Y, Cheng YC, Lee WM, Ye K \& Hu D 2015 Slc15a1 is involved in the transport of synthetic F5-peptide into the seminiferous epithelium in adult rat testes. Scientific Reports 5 16271. (https://doi.org/10.1038/ srep16271)

Sudhakar A \& Boosani CS 2008 Inhibition of tumor angiogenesis by tumstatin: insights into signaling mechanisms and implications in cancer regression. Pharmaceutical Research 25 2731-2739. (https://doi. org/10.1007/s11095-008-9634-z)

Sun M, Connizzo BK, Adams SM, Freedman BR, Wenstrup RJ, Soslowsky LJ \& Birk DE 2015 Targeted deletion of collagen $V$ in tendons and ligaments results in a classic Ehlers-Danlos syndrome joint phenotype. American Journal of Pathology 185 1436-1447. (https://doi.org/10.1016/j. ajpath.2015.01.031)

Tanaka T, Wakabayashi T, Oizumi H, Nishio S, Sato T, Harada A, Fujii D, Matsuo Y, Hashimoto T \& Iwatsubo T 2014 CLAC-P/collagen type XXV is required for the intramuscular innervation of motoneurons during neuromuscular development. Journal of Neuroscience 34 1370-1379. (https://doi.org/10.1523/JNEUROSCI.2440-13.2014)

Tang J \& Saito T 2018a A novel fragment derived from laminin-411 facilitates proliferation and differentiation of odontoblast-like cells. BioMed Research International 2018 9465383. (https://doi.org/ 10.1155/2018/9465383)

Tang J \& Saito T 2018b iMatrix-511 stimulates the proliferation and differentiation of MDPC-23 cells into Odontoblastlike phenotype. Journal of Endodontics 44 1367-1375. (https://doi.org/10.1016/j. joen.2018.05.018)

Timpl R, Wiedemann H, van Delden V, Furthmayr H \& Kühn K 1981 A network model for the organization of type IV collagen molecules in basement membranes. European Journal of Biochemistry 120 203-211. (https://doi.org/10.1111/j.1432-1033.1981.tb05690.x)

Toss MS, Miligy IM, Gorringe KL, Aleskandarany MA, Alkawaz A, Mittal K, Aneja R, Ellis IO, Green AR \& Rakha EA 2019 Collagen (XI) alpha-1 chain is an independent prognostic factor in breast ductal carcinoma in situ. Modern Pathology 32 1460-1472. (https://doi.org/10.1038/s41379019-0286-9)

Ustun Y, Reibetanz M, Brachvogel B, Nischt R, Eckes B, Zigrino P \& Krieg T 2019 Dual role of laminin511 in regulating melanocyte migration and differentiation. Matrix Biology 80 59-71. (https://doi.org/10.1016/j. matbio.2018.09.006)

Virtanen I, Lohi J, Tani T, Korhonen M, Burgeson RE, Lehto VP \& Leivo I 1997 Distinct changes in the laminin composition of basement membranes in human seminiferous tubules during development and degeneration. American Journal of Pathology 150 1421-1431.

Vogl AW, Vaid KS \& Guttman JA 2008 The Sertoli cell cytoskeleton. Advances in Experimental Medicine \& Biology 636 186-211. (https:// doi.org/10.1007/978-0-387-09597-4_11)

Vogl AW, Young JS \& Du M 2013 New insights into roles of tubulobulbar complexes in sperm release and turnover of blood-testis barrier. International Review of Cell \& Molecular Biology 303 319-355. (https:// doi.org/10.1016/B978-0-12-407697-6.00008-8)

Vogl AW, Du M, Wang XY \& Young JS 2014 Novel clathrin/actinbased endocytic machinery associated with junction turnover in the seminiferous epithelium. Seminars in Cell \& Developmental Biology 30 55-64. (https://doi.org/10.1016/j.semcdb.2013.11.002)

Walia A, Yang JF, Huang YH, Rosenblatt MI, Chang JH \& Azar DT 2015 Endostatin's emerging roles in angiogenesis, lymphangiogenesis, disease, and clinical applications. Biochimica \& Biophysica Acta 1850 2422-2438. (https://doi.org/10.1016/j.bbagen.2015.09.007)

Wan HT, Mruk DD, Li SY, Mok KW, Lee WM, Wong CKC \& Cheng CY 2013 p-FAK-Tyr397 regulates spermatid adhesion in the rat testis via its effects on F-actin organization at the ectoplasmic specialization. 
American Journal of Physiology. Endocrinology \& Metabolism 305 E687E699. (https://doi.org/10.1152/ajpendo.00254.2013)

Wan HT, Mruk DD, Wong CKC \& Cheng CY 2014 Perfluorooctanesulfonate (PFOS) perturbs male rat Sertoli cell blood-testis barrier function by affecting F-actin organization via p-FAK-Tyr407 - an in vitro study. Endocrinology 155 249-262. (https://doi.org/10.1210/en.2013-1657)

Willumsen N, Bager C \& Karsdal MA 2019 Matrix metalloprotease generated fragments of type $\mathrm{VI}$ collagen have serum biomarker potential in cancer - a proof of concept study. Translational Oncology 12 693698. (https://doi.org/10.1016/j.tranon.2019.02.004)

Wong EW \& Cheng CY 2013 NC1 domain of collagen alpha3(IV) derived from the basement membrane regulates Sertoli cell blood-testis barrier dynamics. Spermatogenesis $\mathbf{3}$ e25465. (https://doi.org/10.4161/ spmg.25465)

Wong EWP, Mruk DD \& Cheng CY 2008 Biology and regulation of ectoplasmic specialization, an atypical adherens junction type, in the testis. Biochimica \& Biophysica Acta 1778 692-708. (https://doi. org/10.1016/j.bbamem.2007.11.006)

Yan HHN \& Cheng CY 2006 Laminin $\alpha 3$ forms a complex with $\beta 3$ and $\gamma 3$ chains that serves as the ligand for $\alpha 6 \beta 1$-integrin at the apical ectoplasmic specialization in adult rat testes. Journal of Biological Chemistry 281 17286-17303. (https://doi.org/10.1074/jbc.M513218200)

Yan HHN, Mruk DD, Lee WM \& Cheng CY 2007 Ectoplasmic specialization: a friend or a foe of spermatogenesis? BioEssays: News and Reviews in
Molecular, Cellular and Developmental Biology 29 36-48. (https://doi. org/10.1002/bies.20513)

Yan HHN, Mruk DD, Wong EW, Lee WM \& Cheng CY 2008 An autocrine axis in the testis that coordinates spermiation and blood-testis barrier restructuring during spermatogenesis. PNAS 105 8950-8955. (https:// doi.org/10.1073/pnas.0711264105)

Yasuda J, Fukui K, Okada M \& Yamawaki H 2017 T3 peptide, a fragment of tumstatin, stimulates proliferation and migration of cardiac fibroblasts through activation of Akt signaling pathway. Naunyn-Schmiedeberg's Archives of Pharmacology 390 1135-1144. (https://doi.org/10.1007/ s00210-017-1413-0)

Yasuda J, Okada M \& Yamawaki H 2019 Protective effect of T3 peptide, an active fragment of tumstatin, against ischemia/reperfusion injury in rat heart. Journal of Pharmacological Sciences 139 193-200. (https://doi. org/10.1016/j.jphs.2019.01.010)

Received 2 July 2019

First decision 19 August 2019

Revised manuscript received 9 September 2019

Accepted 3 October 2019 